\title{
PROTECTIVE ACTIVITY OF ASPARAGUS RACEMOSUS IN METHOTREXATE-INDUCED LIVER TOXICITY IN WISTAR RATS
}

\author{
ARUL DANIEL J, SUSMITA DAS, NEETHU JAYAN, ASHA DEVI S* \\ Department of Biomedical Sciences, School of Bioscience and Technology, Vit, Vellore, Tamil Nadu, India. \\ Email: ashaselvaraj74@gmail.com
}

Received: 16 April 2018, Revised and Accepted: 25 May 2018

\section{ABSTRACT}

Objectives: Various clinically available drugs along with the beneficial action also have drastic side effects due to chronic exposure. In liver, these resulting side effects can be over production of reactive oxygen species, which will further lead to oxidative stress and hepatotoxicity. Therefore, as a preventive measure, the protective role of herbal extracts is being evaluated because of its high success rate and low toxic effects. The primary aim of this study was to evaluate the efficiency of the protective role of Asparagus racemosus is evaluated and studied against methotrexate (MTX)-induced hepatic damage in male Wistar albino rats.

Methods: The course of the study was for 14 days. During this experimental study, the animals were categorized into four groups with six rats per group. Group I (positive control) which was treated with normal saline, Group II (negative control) with MTX 20 mg/kg of body weight on $12^{\text {th }}$ day, Group III with A. racemosus $300 \mathrm{mg} / \mathrm{kg}$ of body weight + MTX $20 \mathrm{mg} / \mathrm{kg}$ on $12^{\text {th }}$ day, and Group IV with A. racemosus $100 \mathrm{mg} / \mathrm{kg}$ of body weight + MTX $20 \mathrm{mg} / \mathrm{kg}$ on $12^{\text {th }}$ day. On $14^{\text {th }}$ day, the animals were sacrificed, and histopathological as well as antioxidant assays were performed.

Results and Conclusion: Assays revealed high lipid peroxidation level and low antioxidant levels in Group II. Meanwhile, in Group III and IV, the levels were restored near to control, which supported the protective role of A. racemosus against MTX-induced hepatic damage. Histopathology evaluation also supported the above-mentioned findings.

Keywords: Hepatotoxicity, Lipid peroxidation, Methotrexate, Reactive oxygen species, Asparagus racemosus.

(C) 2018 The Authors. Published by Innovare Academic Sciences Pvt Ltd. This is an open access article under the CC BY license (http://creativecommons. org/licenses/by/4. 0/) DOI: http://dx.doi.org/10.22159/ajpcr.2018.v11i9.26728

\section{INTRODUCTION}

Methotrexate (MTX) is a chemotherapeutic agent widely used for treating cancer, psoriasis, dermatomyositis, sarcoidosis, and rheumatoid arthritis [1]. MTX mainly interferes with the growth rate of highly reproducing cells such as cancer cells, bone marrow cells, etc. However, the drug efficiency of MTX is limited and thus chronic high-dosage administration leads to hematopoietic suppression, hepatotoxicity including cellular necrosis and cirrhosis of the liver [2-4]. Studies recommend that MTX-induced liver toxicity is associated with high production of ROS (reactive oxygen species) and failure of antioxidant defense system due to reduction in glutathione (GSH) supply [5]. High concentration of ROS, in turn, enhances the lipid peroxidation level as well unsaturated fatty acid accumulation in cell membranes.

Asparagus racemosus of family Liliaceae is a prevalent consuming vegetable plant grown in almost all fractions of the continents Asia, Australia, and Africa. The root of this plant possesses certain biological properties such as antidiabetic, anti-arthritic, anticancer, antifungal, etc [6,7]. This plant has already been used as a remedy for diseases such as diarrhea, dysentery, and nervous breakdown [8]. As far as concern, very less information is available on the hepatoprotective role of $A$. racemosus on the induced liver injury. The utilization of herbal extracts have cure for many diseases without any toxic side effects and thus have a high success rate. Hence, to evaluate the efficiency of the protective role of $A$. racemosus, the present study has been conducted where an aqueous extract of the plant is administered to female Wistar albino rats with MTX-induced hepatic damage.

\section{METHODS}

\section{Chemicals}

The tablets of MTX were commercially acquired from the pharmacy and were used by dissolving in normal saline solution. All the chemicals and reagents used for conducting the experiments were analytically graded.

\section{Extract preparation from plant root}

The roots of the medicinal herb A. racemosus were procured from the localities of Vellore around August, 2017 and authentication done from Horticultural Research Station, Yercaud, Tamil Nadu, India. The fresh roots collected were cleaned up well and shade dried for a week at $45^{\circ} \mathrm{C}$. The thoroughly dried roots were powdered finely by multiple grinding processes to make up $100 \mathrm{~g}$ with the help of an electric grinder. The fine powder obtained was sieved out to remove adducts and impurities and was mixed in water. The mixture was kept at room temperature for overnight; and on next day, the mixture is filtered separately using filter paper for collecting the root extract. The extract solution is then dried completely at $45^{\circ} \mathrm{C}$ for a time span of $4-5 \mathrm{~h}$ in a hot air oven. The dried extract was then collected in vials and stored at $4^{\circ} \mathrm{C}$. For experimental requirements, it was used by diffusing in distilled water.

\section{Preparation of animals for experiment}

A total of 24 female Wistar albino rats with weights differing in the span of 150-200 g resorted for the present experimental study. The rats were kept in normal room temperature $\left(24 \pm 2^{\circ} \mathrm{C}\right)$ and contained $12 \mathrm{~h}: 12 \mathrm{~h}$ light and dark cycles. They were provided with usual laboratory diet. The approval for the experimental 1 protocol was given by the Animal Ethical Committee, (VIT/IAEC/14Nov/08) VIT, Vellore.

\section{Experimental design}

The animals were erratically allocated into four groups with six rats in each group. The total time span for the study was 14 days. Group I containing positive control animals were tended with normal saline solution orally for entire 14 days of study. The animals in Group II were tended with only MTX mixed in normal saline on $12^{\text {th }}$ day of study, and 
it served as the negative control. The MTX was given to the animals in the mode of intraperitoneal injection. A low dosage of the aqueous root extract of $A$. racemosus with the concentration of $100 \mathrm{mg} / \mathrm{kg}$ of body weight was given orally to the Group III animals. Group IV animals were considered as high dosage group and were administered with aqueous root extract of $A$. racemosus with the concentration of $300 \mathrm{mg} / \mathrm{kg}$ of bodyweight. On $12^{\text {th }}$ day, Group III and Group IV were injected with MTX intraperitoneally in the concentration of $20 \mathrm{mg} / \mathrm{kg}$ of body weight. The dosages were provided to animals based on Devi et al.

The body weights of the animals were estimated on the first and last days of the experimental studies. On $15^{\text {th }}$ day, 24 h later to last dosage, the animals were sacrificed; and in vials, the blood was collected through heart puncture. Later, the liver tissue sample was carefully excised from the animal and blot dried after washing in normal saline solution to clean off the stains of blood. The dried liver samples were then weighed and homogenized for carrying out the histopathological and other in vivo antioxidant assays.

\section{Estimation of biochemical parameters}

The blood samples collected in vials from animals were allowed to develop clots in normal environmental conditions for few minutes and later centrifuged to separate out the serum from blood clots at $3000 \mathrm{rpm}$ for $10 \mathrm{~min}$ at a temperature of $4^{\circ} \mathrm{C}$. The serum thus separated was used in evaluating the levels of various marker enzymes alkaline phosphatase (ALP) and alkaline transferase (ALT) in the liver. It was carried out with the help of commercially available kits for estimating the marker enzymes from Autospan Diagnostics Pvt. Ltd., India. The total protein content in the blood serum was calculated based on the protocol by Lowry et al. (1951)

\section{Homogenate solution preparation}

Liver homogenate solution of concentration $10 \%$ was prepared using $0.1 \mathrm{M}$ ice-cold phosphate buffer with $\mathrm{pH} 7.4$ and $1.17 \% \mathrm{KCl}$. A part of the homogenate thus obtained was used in estimating lipid peroxidation and reduced GSH status. The remaining part of homogenate solution was subjected to centrifugation at $4^{\circ} \mathrm{C}$ for $10 \mathrm{~min}$ at $10,000 \mathrm{rpm}$. The supernatant solution separated out was utilized in conducting antioxidant enzymatic assays as follows: Catalase (CAT) and superoxide dismutase (SOD).

\section{Assessment of activity of GSH peroxidase (GPx)}

With the help of electron donor, GSH, GPx prevents free radical formation by reducing peroxyl radicals. GPx assay was carried out based on the protocol developed by Rotruck et al. To $0.4 \mathrm{~mL}$ phosphate buffer with ph 7.0 and $0.4 \mathrm{M}, 0.1 \mathrm{~mL}$ of homogenate supernatant was added along with $0.1 \mathrm{~mL}$ sodium azide, $2.5 \mathrm{mM} \mathrm{H}_{2} \mathrm{O}_{2}, 0.2 \mathrm{~mL}$ of $4 \mathrm{mM} \mathrm{GSH}$, and $0.2 \mathrm{~mL}$ distilled water. $10 \%$ TCA was added to the mixture after incubating for $10 \mathrm{~min}$ at room temperature, followed by centrifugation for $10 \mathrm{~min}$ at $1500 \mathrm{rpm}$. From supernatant thus obtained, $1 \mathrm{~mL}$ was mixed with $0.5 \mathrm{~mL}$ of DTNB (Ellman's Reagent) and about $4 \mathrm{~mL}$ of $0.3 \mathrm{M}$ disodium hydrogen phosphate buffer. The 1absorbance value for the resulting mixture was taken at $412 \mathrm{~nm}$, and the results were expressed as $\mu \mathrm{g}$ of GSH utilized/min mg protein.

\section{Assessment of lipid peroxidation}

Estimating the quantity of end product of lipid peroxidation, malondialdehyde (MDA), can detect the extent of oxidative stress happened quantitatively. Hence, it acts as the biomarker in estimating the cell oxidative stress levels. Lipid peroxidation estimation was carried out according to the protocol of Okhawa et al. (1971). To $1 \mathrm{~mL}$ of tissue homogenate, $1 \mathrm{~mL}$ TCA $(10 \%)$ was added at incubated for $10 \mathrm{~min}$ at room temperature, followed with centrifugation at $4^{\circ} \mathrm{C}$ for $15 \mathrm{~min}$ at $2500 \mathrm{rpm}$. To $1 \mathrm{~mL}$ of TBA $(0.67 \%), 1 \mathrm{~mL}$ of supernatant was added and kept in water bath for $20 \mathrm{~min}$. The mixture tubes were then cooled under tap water and later $1 \mathrm{~mL}$ of distilled water and $5 \mathrm{~mL}$ n-butanol: pyridine was added separately to each tube. The mixture was again centrifuged and the butanol layer formed on the top was collected, and the absorbance reading was taken at $532 \mathrm{~nm}$. The result calculated was denoted as n moles MDA formed/mg protein.

\section{Assessment of SOD}

The enzyme SOD acts as an antagonist for free radicals which are highly reactive like hydroxyl radicals by converting it into oxygen and $\mathrm{H}_{2} \mathrm{O}_{2}$. The protocol by Marklund and Marklund et al., (1974) for auto-oxidation method of pyrogallol was used to determine enzymatic activity. To 0.5 $\mathrm{mL}$ of tissue homogenate supernatant, $0.15 \mathrm{~mL}$ chloroform and $0.25 \mathrm{~mL}$ absolute ethanol were added, and kept in a shaker for $15 \mathrm{~min}$ followed by centrifugation. $2 \mathrm{~mL}$ Tris HCL with $\mathrm{pH}$ value 8.2 and $0.1 \mathrm{M}$ was added to $0.5 \mathrm{~mL}$ of supernatant acquired along with $1 \mathrm{~mL}$ of distilled water and $0.5 \mathrm{~mL}$ solution of pyrogallol. The absorbance reading for the final mixture is taken at $420 \mathrm{~nm}$ with 1-min interval for a total of $3 \mathrm{~min}$. The results were expressed as $\mathrm{U} / \mathrm{mg}$ protein.

\section{Assessment of CAT activity}

CAT enzyme helps in the conversion of $\mathrm{H}_{2} \mathrm{O}_{2}$ developed during toxic reactions inside the body, to water, and oxygen. To $0.1 \mathrm{~mL}$ of tissue homogenate, $1.9 \mathrm{~mL}$ of phosphate buffer along with $1 \mathrm{~mL} \mathrm{of} \mathrm{H}_{2} \mathrm{O}_{2}$ was added. The protocol followed was based on the method of Beers and Sizer et al. (1952). The readings of the absorbance were taken at $240 \mathrm{~nm}$ for $3 \mathrm{~min}$ with an interval of $1 \mathrm{~min}$. The results of enzyme activity were expressed in $\mathrm{mM} \mathrm{H}_{2} \mathrm{O}_{2}$ decomposed/min/mg protein.

\section{Histopathological evaluation}

The liver samples resected from the animals of each group were stored in a neutral formalin buffer (10\%). Using an automated tissue processor, the liver tissue samples were processed and later fixed in wax. With the help of Leica microtome RM 2155, the tissue sections were sliced on a thickness of $5 \mu \mathrm{m}$ and later stained with Eosin and Hematoxylin ( $E$ and $\mathrm{H})$. The slides after staining were visualized under a light microscope.

\section{Statistical evaluation}

The result data were expressed in mean \pm standard error mean, followed by the statistical analysis using ANOVA and Dunnett's test. Statistical significance was considered at $\mathrm{p}<0.05$. Statistical significance studies were executed using Graphpad Instat Software Inc., of version 3.06, San Diego, USA.

\section{RESULTS}

\section{Body and organ weight}

The variations between initial and final body weight as well as changes in liver weight are shown below in Table 1 . In Group II, the animals body weight got increased a little bit due to the treatment of MTX compared to the normal controls of Group I whereas in both Group III and Group IV due to the restoration activity of aqueous root extract of $A$. racemosus, the body weight is more or less similar to Group I. The liver weight in Group II, Group III, and Group IV did not show any significant difference. Hence, it can be concluded that pretreated with aqueous root extract of $A$. racemosus has no effect on organ weight.

\section{Biochemical estimation}

The levels of liver marker enzymes and serum total protein are depicted in Figs. 1-3. In Group II which was treated with MTX, the levels of liver marker enzymes ALT (Fig. 1) and ALP (Fig. 2) were increased drastically $(p<0.05)$ compared to the normal control of Group I. This elevation depicts the presence of liver damage caused by the induced MTX toxicity. A. racemosus treated Group III and IV before MTX treatment showed a decrease in the levels ALT (Fig. 1) and ALP (Fig. 2) marker enzymes, which indicate that the aqueous root extract of $A$. racemosus has counteracted the toxicity action of MTX and restored back the level to normal.

The levels of serum total protein (Fig. 3) also decreased drastically in MTX administered Group II whereas the serum protein levels were restored close to normal in Group III and IV due to the administration of aqueous root extract of $A$. racemosus when compared with the normal control Group I.

\section{Antioxidant assays}

Table 2 shows the variations in levels of lipid peroxidation, antioxidant enzymes as follows: SOD, CAT, and GSH peroxidizes (GPx). 
Table 1: The activity of methotrexate on body weight and organ weight of the experimental groups of animals with or without the treatment of aqueous root extract of Asparagus racemosus

\begin{tabular}{lllll}
\hline Groups & Initial body weight (mg) & Final body weight (mg) & Percentage increased (\%) & Absolute organ weight (g) \\
\hline Group I (control) & $178.33 \pm 3.28$ & $190.66 \pm 2.96$ & $6.47 \pm 0.27$ & $0.17 \pm 0.0014$ \\
Group II (negative) & $230 \pm 16.64$ & $242.66 \pm 15.98$ & $5.29 \pm 0.62$ & $0.176 \pm 0.0048$ \\
Group III (low dosage) & $172.66 \pm 5.20$ & $183.33 \pm 4.91$ & $5.83 \pm 0.32$ & $0.174 \pm 0.0053$ \\
Group IV (medium dosage) & $192.33 \pm 19.42$ & $202.66 \pm 20.53$ & $5.08 \pm 0.21$ & $0.1703 \pm 0.0006$ \\
\hline
\end{tabular}

The result values are represented as mean value \pm standard error mean; $n=6$ in each group; ${ }^{*}<0.01$ and ${ }^{* *} p<0.05$ considered statistically significant. Comparisons are as follows: (a) Group II when compared with normal group. (b) Group III and IV when compared with negative control Group II. Statistical analysis using ANOVA, followed by Dunnett's comparison test., A. racemosus: Asparagus racemosus

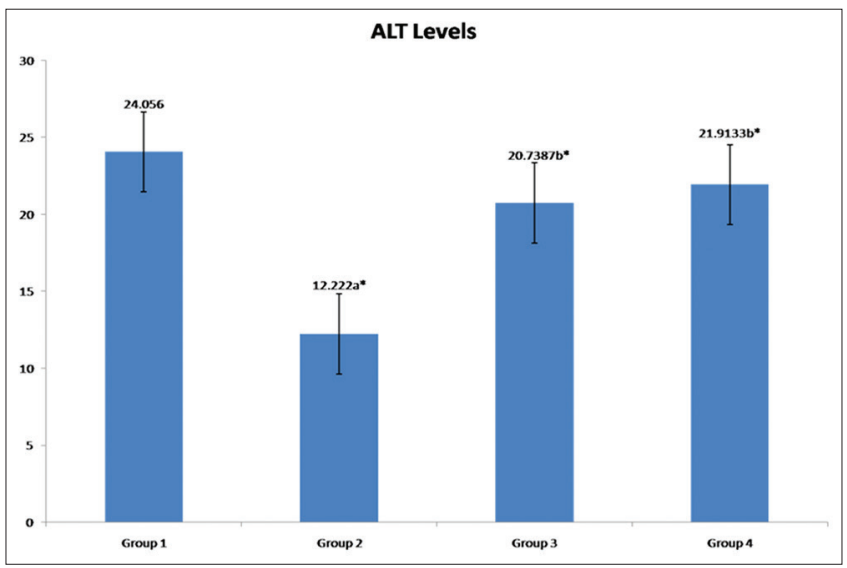

Fig. 1: The activity of methotrexate with or without the treatment of Asparagus racemosus on alkaline transferase lipid marker levels of the experimental groups. Values are mean $\pm S E M n=6$.

${ }^{*} \mathbf{p}<0.01$ and comparisons were made as follows: a - Group I versus Group II-V; b - Group II versus Group III-V

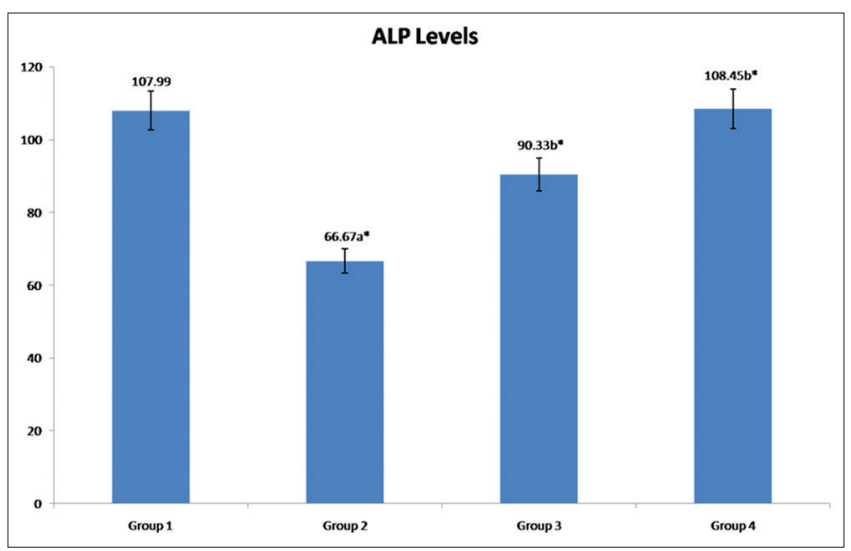

Fig. 2: The activity of methotrexate with or without the treatment of Asparagus racemosus on alkaline phosphatase lipid marker levels of the experimental groups. Values are mean $\pm S E M n=6$.

${ }^{*} \mathbf{p}<0.05$ and comparisons were made as follows: a - Group I versus Group II-V; b - Group II versus Group III-V

Group II clearly showed the elevated levels of lipid peroxidation due to the action of MTX administered whereas the levels got reduced in Group III and IV due to the pretreatment with A. racemosus when compared to the positive control Group I. Both Group III and IV gave results close to the Group I, which suggests the restoration role of aqueous root extract of $A$. racemosus.

The antioxidant SOD, CAT, and GPx enzyme levels significantly got reduced in MTX pretreated Group II when compared to normal control Group I. This shows the toxic action of MTX which resulted in the impaired action of antioxidant enzymes due to antioxidant depletion. In Group III and IV,

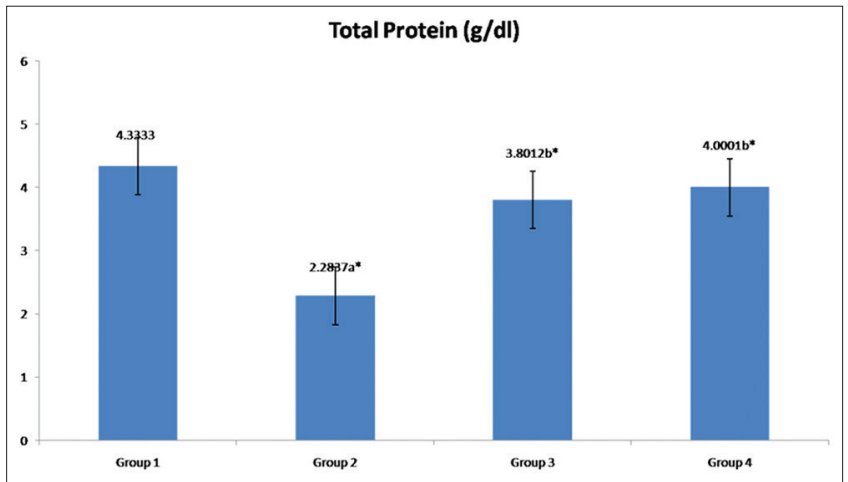

Fig. 3: The activity of methotrexate with or without the treatment of Asparagus racemosus on total protein (g/dL) levels of the experimental groups. Values are mean \pm SEM $n=6 .{ }^{*} p<0.05$ and comparisons were made as follows: a - Group I versus Group II-V; b - Group II versus Group III-V

the antioxidant enzyme levels were increased near to the normal level when compared to control Group I. This suggests the protective role of the aqueous extract of $A$. racemosus against the induced toxicity.

\section{Histopathological Examinations}

Fig. 4a depicts the normal control Group I which showed normal histology. Fig. 4b depicts the MTX pretreated Group II which showed damaged histology due to dilated and congested central veins as well as increase in the number of Kupffer cell in the sinusoids. It also showed chronic inflammatory cell infiltration, increase in eosinophil, and destroyed periportal hepatocytes. Fig. 4c depicts the A. racemosus extract treated Group III where more normal hepatocytes and few hepatocytes show necrosis were observed. Similarly, Fig. $4 \mathrm{~d}$ of A. racemosus treated Group IV also showed minimal inflammatory cell infiltration in the portal tract.

\section{DISCUSSION}

The liver is the main xenobiotic metabolism site, and hence, increased the amount of toxicants hinder the normal function of the liver by reducing the antioxidant reserve [9]. One of the factors which increase the level of toxicity is the chronic overdose of the drug. Chemotherapeutic drugs are considered to have acute side effects in different organ systems. Studies revealed that chronic overdose intake of MTX results in liver injury $[10,11]$. MTX inhibits the cytoplasmic NADP dehydrogenases and NADP malic enzymes which are required to maintain the reduced state of GSH reductase $[12,13]$. Reduction in cellular GSH, in turn, reduces the effectiveness of antioxidant defense of the liver against the increased ROS and thereby leading to hepatotoxicity $[14,15]$

The interpreted data from this study suggest that the levels of lipid peroxidation were increased significantly whereas other antioxidant enzyme levels including GSH were decreased in the negative control group compared to the positive control. The levels ALT and ALP, which are the markers of hepatic injury, were also elevated in the negative group. The reduced levels of these antioxidant enzymes were restored back again, and the ALT and ALP levels were normalized in groups, 
Table 2: Action of MTX on the antioxidant enzyme parameters and lipid peroxidation in the liver organs of experimental animals with or without $A$. racemosus treatment

\begin{tabular}{lllll}
\hline Parameters & Group I (control) & Group II (negative) & Group III (low dosage) & Group IV (high dosage) \\
\hline Lipid peroxidation (n moles/mg protein) & $0.044 \pm 0.005$ & $0.072 \pm 0.0007 \mathrm{a}^{* *}$ & $0.040 \pm 0.0068 \mathrm{~b}^{* *}$ & $0.051 \pm 0.0036 \mathrm{~b}^{* *}$ \\
CAT ( $\mu$ mole of H2O2 consumed/min mg protein) & $0.136 \pm 0.0008$ & $0.115 \pm 0.0007 \mathrm{a}^{*}$ & $0.130 \pm 0.0006 \mathrm{~b}^{*}$ & $0.127 \pm 0.004 \mathrm{~b}^{*}$ \\
SOD (U/mg protein) & $3.831 \pm 0.067$ & $1.813 \pm 0.307 \mathrm{a}^{*}$ & $3.311 \pm 0.224 \mathrm{~b}^{* *}$ & $3.023 \pm 0.342 \mathrm{~b}^{* *}$ \\
GSH peroxidase $(\mu \mathrm{g}$ of GSH used/min/mg protein) & $23.991 \pm 0.809$ & $14.874 \pm 1.078 \mathrm{a}^{*}$ & $20.766 \pm 1.518 \mathrm{~b}^{* *}$ & $21.886 \pm 1.797 \mathrm{~b}^{* *}$ \\
\hline
\end{tabular}

The result values are represented as mean value \pm standard error mean with $n=6$ in every group ; ${ }^{*} \mathrm{p}<0.01$ and ${ }^{* *} \mathrm{p}<0.05$ considered statistically significant. Comparisons are as follows: a - Group II when compared with normal group. b - Group III and IV when compared with negative control Group II. Statistical analysis using ANOVA, followed by Dunnett's comparison test. GSH: Glutathione, A. racemosus: Asparagus racemosus, CAT: Catalase, SOD: Superoxide dismutase

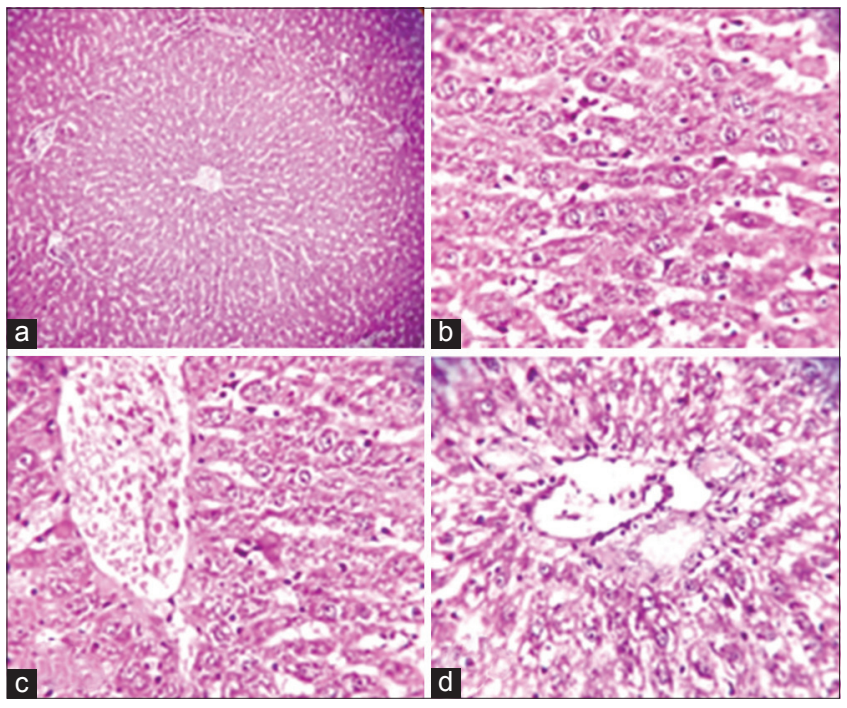

Fig. 4: Histopathological section showing the effects of administration of methotrexate and pretreatment with or without Asparagus racemosus (a) normal control $(\mathrm{H}$ and $\mathrm{E} \times 100)$

(b) negative treated with $20 \mathrm{mg} / \mathrm{kg}$ b.wt MTX (H and E $\times 400$ ) (c) Asparagus racemosus $100 \mathrm{mg} / \mathrm{kg}$ b.wt + MTX $20 \mathrm{mg} / \mathrm{kg} \mathrm{b.wt}$ (H and E $\times 400$ ) (d) Asparagus racemosus $300 \mathrm{mg} / \mathrm{kg}$ b.wt + MTX $20 \mathrm{mg} / \mathrm{kg} \mathrm{b.wt} \mathrm{(H} \mathrm{and} \mathrm{E} \times 400)$

which were administered with $A$. racemosus. Histopathological results also supported the protective role of $A$. racemosus. The phytochemical studies carried out suggest the presence of flavonoids in aqueous extract of $A$. racemosus, and these flavonoids have been reported to possess hepatoprotective activity [16]. Phytochemical analysis has proved that $A$. racemosus root contains different type of compounds such as phytosterols, phenols, flavonoids, antioxidants [17], and various types of saponin [18]. Hence, it can be concluded that A. racemosus has inhibitory action against lipid peroxidation, hydroxyl, and superoxide radicals.

\section{CONCLUSION}

Hence, it can be concluded that the study provides strong evidence on the protective role of $A$. racemosus on MTX-induced liver injury in Wistar rats. The hepatoprotective property of $A$. racemosus restored back the levels of the antioxidant enzymes such as SOD, CAT, and GPx in the liver tissues. However, further additional comprehensive studies on the clinical and molecular levels are needed for understanding the exact course of action.

\section{AUTHOR'S CONTRIBUTION}

All authors have equal contribution toward this manuscript. The study conception and experimental design by S. Asha Devi, acquisition of data and drafting of manuscript by Susmita Das, Neethu Jayan,analysis and interpretation of data by Arul Daniel J.

\section{CONFLICTS OF INTEREST}

There are no conflicts of interest.

\section{ACKNOWLEDGMENT}

The authors are grateful to the VIT, Vellore, for the seed money and infrastructural support for the completion of the whole experimental study.

\section{REFERENCES}

1. Bayram M, Ozogul C, Dursun A, Ercan ZS, Isik I, Dilekoz E. Light and electron microscope examination of the effects of methotrexate on the endosalpinx. Eur J Obstet Gynecol Reprod Bio 2005;120:96-103.

2. Tobias H, Auerbach R. Hepatotoxicity of long term methotrexate therapy for psoriasis. Arch Intern Med 1973;132:391-6.

3. Hytiroglou P, Tobias H, Saxena R, Abramidou M, Papadimitriou CS, Theise ND, et al. The canals of hering might represent a target of methotrexate hepatic toxicity. Am J Clin Pathol 2004;121:324-9.

4. Barak AJ, Tuma DJ, Beckenhauer HC. Methotrexate hepatotoxicity. J Am Coll Nutr 1984:3:93-6.

5. Cetiner M, Sener G, Sehirli AO, Demiralp EE, Ercan F, Sirvanci S, et al. Taurine protects against methotrexate-induced toxicity and inhibits leukocyte death. Toxicol Appl Pharmacol 2005;209:39-50.

6. Edenharder R. Antimutagenic activity of vegetable and fruit extracts against in vitro benzo(a)pyrene. Z Gesamte Hyg 1990;36:144-8.

7. Shimoyamada M, Suzuki M, Sonta H, Maruyama M, Okubo K. Antifungal activity of the saponin fraction obtained from asparagus and its active principle. Agric Biol Chem 1990;54:2553-7.

8. Nadkarni AK. India Materia Medica. Bombay: Popular Prakashan; 1976. p. 151-5.

9. Asha DS, Blossom B. Hepatoprotective role of Spirulina fusiformis on methotrexate induced liver injury in Wistar rats. Res J Biotechnol 2016;11:58-64.

10. Sener G, Demiralp EE, Cetiner M, Ercan F, Yegen BC. $\beta$ glucan ameliorates methotrexate-induced oxidative organ injury via its antioxidant and immunomodulatory effects. Eur J Pharmacol 2006b;542:170-8.

11. Uraz S, Tahan V, Aygun C, Eren F, Unluguzel G, Yuksel M, et al. Role of ursodeoxycholic acid in prevention of methotrexate-induced liver toxicity. Dig Dis Sci 2008;53:1071-7.

12. Babiak RM, Campello AP, Carnieri EG, Oliveira MB. Methotrexate: Pentose cycle and oxidative stress. Cell Biochem Funct 1998;16:283-93.

13. Barak AJ, Tuma DJ, Beckenhauer HC. Methotrexate hepatotoxicity. J Am Coll Nutr 1984;3:93-6.

14. Sabina EP, Samuel J, Ramya SR, Patel S, Mandal N, Pranatharthiharan P, et al. Hepatoprotective and antioxidant potential of Spirulina fusiformis on acetaminophen induced hepatotoxicity in mice. Int J Integr Biol 2009;6:1-5.

15. Kumar RS, Daniel JA, Jeyachristy SA, Devi SA. Hepatoprotective role of Abutilon indicum on Lead induced liver injury in Wistar rats. Int $\mathrm{J}$ Pharm 2016;10:36-9

16. Om FR, Kumar MR, Mani TT, Niyas KM, Kumar BS, Phaneendra P, et al. Hepatoprotective activity of "Asparagus racemosus root" on liver damage caused by paracetamol in rats. Indian J Novel Drug Deliv 2011;3:112-7.

17. Suchismita R, Shrabani P, Shreya ML, Koushik D, Arpita P, Animesh S, et al. Phytochemical analysis, antimicrobial activity and assessment of potential compounds by thin layer chromatography of ethanol fraction of Asparagus racemosus roots. Int J Pharm Pharm Sci 2014;6:367-70.

18. Rachana G, Bhavna S, Nilesh G, Ghanshyam P, Bhavna P. Isolation and characterization of Shatavarin IV from root of Asparagus racemosus willd. Int J Pharm Pharm Sci 2015;7:362-5. 